\title{
Validation of the Erlangen Score Algorithm for Differential Dementia Diagnosis in Autopsy-Confirmed Subjects
}

\author{
Charisse Somers $^{\mathrm{a}, 1}$, Piotr Lewczuk ${ }^{\mathrm{b}, \mathrm{c}, 1}$, Anne Sieben $^{\mathrm{d}}$, Christine Van Broeckhoven $^{\mathrm{e}, \mathrm{f}}$, \\ Peter Paul De Deyn ${ }^{\mathrm{a}, \mathrm{d}, \mathrm{g}}$, Johannes Kornhuber ${ }^{\mathrm{b}}$, Jean-Jacques Martin ${ }^{\mathrm{d}}$, Maria Bjerke ${ }^{\mathrm{a}, 2}$ \\ and Sebastiaan Engelborghs ${ }^{\mathrm{a}, \mathrm{g}, 2, *}$ \\ ${ }^{a}$ Reference Center for Biological Markers of Dementia (BIODEM), Laboratory of Neurochemistry \\ and Behavior, Institute Born-Bunge, University of Antwerp, Antwerp, Belgium \\ ${ }^{\mathrm{b}}$ Department of Psychiatry and Psychotherapy, Universitätsklinikum Erlangen, and Friedrich-Alexander \\ Universität Erlangen-Nürnberg, Erlangen, Germany \\ ${ }^{\mathrm{c}}$ Department of Neurodegeneration Diagnostics, Medical University of Biatystok, Biatystok, Poland \\ ${ }^{\mathrm{d}}$ Biobank, Institute Born-Bunge, University of Antwerp, Antwerp, Belgium \\ ${ }^{\mathrm{e}}$ Neurodegenerative Brain Diseases Group, Center for Molecular Neurology, VIB, Antwerp, Belgium \\ ${ }^{\mathrm{f}}$ Laboratory of Neurogenetics, Institute Born-Bunge, University of Antwerp, Antwerp, Belgium \\ ${ }^{\mathrm{g}}$ Department of Neurology and Memory Clinic, Hospital Network Antwerp (ZNA) Middelheim \\ and Hoge Beuken, Antwerp, Belgium
}

Handling Associate Editor: Henrik Zetterberg

Accepted 28 January 2019

\begin{abstract}
. dementia $(n=57)$. neuropathology as a reference.

\footnotetext{
${ }^{1}$ These authors contributed equally to this work.

${ }^{2}$ Joint last authors.

${ }^{*}$ Correspondence to: Prof. Dr. Sebastiaan Engelborghs, University of Antwerp, Reference Center for Biological Markers of
}

Background: Despite decades of research on the optimization of the diagnosis of Alzheimer's disease (AD), its biomarkerbased diagnosis is being hampered by the lack of comparability of raw biomarker data. In order to overcome this limitation, the Erlangen Score (ES), among other approaches, was set up as a diagnostic-relevant interpretation algorithm.

Objective: To validate the ES algorithm in a cohort of neuropathologically confirmed cases with $\mathrm{AD}(n=106)$ and non-AD

Methods: Cerebrospinal fluid (CSF) biomarker concentrations of $A \beta_{1-42}$, T-tau, and P-tau 181 were measured with commercially available single analyte ELISA kits. Based on these biomarkers, ES was calculated as previously reported.

Results: This algorithm proved to categorize AD in different degrees of likelihood, ranging from neurochemically "normal", "improbably having AD", "possibly having AD", to "probably having AD", with a diagnostic accuracy of $74 \%$ using the

Conclusion: The ability of the ES to overcome the high variability of raw CSF biomarker data may provide a useful diagnostic tool for comparing neurochemical diagnoses between different labs or methods used.

Keywords: Alzheimer's disease, amyloid, biomarkers, cerebrospinal fluid, dementia, harmonization, standardization, tau

Dementia (BIODEM), Universiteitsplein 1, BE-2610 Antwerp, Belgium. Tel.: +323265 23 94; Fax: +323 26526 69; E-mail: sebastiaan.engelborghs@uantwerpen.be. 


\section{INTRODUCTION}

Alzheimer's disease (AD) is one of the most frequently occurring neurodegenerative disorders in the Western population and decades of research on the optimization of AD diagnosis has led to the discovery of a validated cerebrospinal fluid (CSF) biomarker profile that reflects the presence of AD pathology in the brain $[1,2]$. This biomarker profile is characterized by lowered CSF levels of amyloid- $\beta$ peptide of 42 amino acids $\left(A \beta_{1-42}\right)$ in combination with elevated levels of total tau-protein (T-tau) and/or tauprotein phosphorylated at threonine $181\left(\mathrm{P}-\operatorname{tau}_{181}\right)$ as described in the IWG-2 criteria and is being used in clinical work-up as well as for research purposes [3, 4]. Although these biomarkers demonstrate sensitivities and specificities of $100 \%$ and $91 \%$, respectively, for confirmation of $\mathrm{AD}$ against healthy controls, sensitivity and specificity values still only reach the $80 \%$ threshold to differentiate $\mathrm{AD}$ against other neurodegenerative disorders ( $80 \%$ and $93 \%$ ) [1, 5]. The optimization of the stratification of patient populations would benefit the success rate of clinical trials with potential disease-modifying drugs against AD.

However, further improvement of the biomarkerbased diagnosis of $\mathrm{AD}$ is being hampered by the lack of comparability of raw biomarker data [6]. These raw data are subjected to interlaboratory variances due to a lack in standardization of sample collection, handling and storage protocols, and due to laboratory-specific cutoff values or different laboratory platforms used [7-11]. This has already been partially addressed by providing standard operating procedures for pre-analytical sample handling [12] as well as recommendations for analytical processes to improve standardization [13-15]. Despite these steps, and provided the ongoing evolution in biomarker research, currently used methods and platforms may be modified. Therefore, much could still be gained by introducing a diagnostic-relevant interpretation algorithm for raw biomarker data.

Accordingly, the Erlangen Score (ES) was set up and previously validated across different patient cohorts, different pre-analytical operating procedures and different analytical platforms as an algorithm to standardize and improve the biomarker-based diagnosis of $\mathrm{AD}[16,17]$. In order to further validate the diagnostic utility of this algorithm for its use in differential AD diagnosis, this study with a neuropathologically confirmed cohort of $\mathrm{AD}$ and non-AD dementia patients was set up.

\section{METHODS}

\section{Study population}

The study cohort consists of 106 patients with a definite diagnosis of $\mathrm{AD}$, either with concomitant but minor non-AD pathology or $\mathrm{AD}$ pathology in pure forms, and 57 patients with a definite diagnosis of non-AD, all confirmed by postmortem neuropathological examination. Non-AD is defined as clinical dementia with a pathological diagnosis not attributed to $\mathrm{AD}$, meanwhile excluding concomitant $\mathrm{AD}$ pathology, consisting of definite frontotemporal lobar degeneration (FTLD; $n=28$ ), vascular dementia $(n=13)$, Lewy body disease (LBD; $n=8$ ), corticobasal degeneration (CBD; $n=1)$, or other including hippocampal sclerosis, arteriosclerosis, cerebral amyloid angiopathy, and cases without specific neuropathological findings $(n=7)$. Definite diagnosis was attained by neuropathological examination of the right hemisphere of the brain, performed at the Institute Born-Bunge (Antwerp, Belgium) by two neuropathologists (JJM and AS). Definite $\mathrm{AD}$ was diagnosed based on $\mathrm{AD}$ neuropathological changes scored using the Montine criteria [18], whereas definite LBD was evaluated using the McKeith classification [19]. Definite vascular disease was rated using the Deramecourt criteria [20]. Definite diagnosis of FTLD was established through the criteria of Cairns [21] and Mackenzie [22, 23]. A definite diagnosis of CBD was confirmed by visual assessment of pathological hallmarks of CBD [24].

The study was conducted according to the revised Declaration of Helsinki and good clinical practice guidelines. This study was approved by the ethics committee of UAntwerp, Antwerp, Belgium (B300201420406). Informed consent was obtained from all subjects.

\section{CSF sampling and analysis}

All CSF samples were obtained following standard collection protocols as previously described [4]. CSF was collected by lumbar puncture (LP) at the L3/L4 or L4/L5 interspace [12] into polypropylene vials. Samples were either frozen immediately and shipped on dry ice to the BIODEM lab or shipped unfrozen within $24 \mathrm{~h}$ after the puncture. Samples were stored at $-80^{\circ} \mathrm{C}$ until analysis.

CSF biomarker concentrations of $\mathrm{A} \beta_{1-42}, \mathrm{~T}$-tau, and $\mathrm{P}-\operatorname{tau}_{181}$ were measured with commercially 
available single analyte ELISA kits (INNOTEST ${ }^{\circledR}$ $\beta$-Amyloid(1-42), INNOTEST $^{\circledR}$ hTau-Ag, and INNOTEST $^{\circledR}$ PhosphoTau(181P), respectively; Fujirebio Europe, Ghent, Belgium) following manufacturer's instructions as previously described [1]. The concentration ranges of the test kits, determined as the highest and lowest calibrator concentration, are described in the package inserts (A $\beta_{1-42}: 125-2000 \mathrm{pg} / \mathrm{mL}$, T-tau: $75-1200 \mathrm{pg} / \mathrm{mL}$, P-tau 181 : $15.6-500 \mathrm{pg} / \mathrm{mL}$ ). Interpretation of the biomarker levels was based on cutoffs previously determined in a cohort of autopsy-confirmed AD patients and cognitively healthy elderly [25]. Levels of $\mathrm{A} \beta_{1-42}<638.5 \mathrm{pg} / \mathrm{ml}, \mathrm{T}$-tau $>296.5 \mathrm{pg} / \mathrm{ml}$, and P-tau $181>56.5 \mathrm{pg} / \mathrm{ml}$ were defined as abnormal.

\section{Erlangen score}

The ES was proposed as an algorithm taking into account the core CSF biomarkers, as previously described [16]. The ES suggests a classification into four diagnostic groups. Depending on the pattern of the biomarker alterations, the CSF results of a given patient are scored between 0 and 4 points (Fig. 1). A CSF result with all biomarkers normal is scored 0 points; a pattern with marginal alterations in one biomarkers group (either $A \beta$ or Tau, but not both) results in the score of 1 ; a CSF result with the alterations in either $A \beta$ metabolism (decreased $A \beta_{1-42}$ concentration or $A \beta_{1-42} / A \beta_{1-40}$ ratio) or tau metabolism (increased concentrations of T-tau and/or P-tau 181 ) but not both is scored 2 points; a result with clear alterations in one biomarkers' group (either $\mathrm{A} \beta$ or Tau) accompanied by marginal alterations in the other group is scored 3 points; clear alterations in both $\mathrm{A} \beta$ and T-tau/P-tau 181 result in 4 points.

\section{Statistical analysis}

Descriptive statistics on all data were performed using SPSS of IBM Statistics, version 24, with significance level defined as $p<0.05$. In spite of an adequate sample size, non-parametric testing was selected as the variances across the groups was heteroscedastic. Demographic data and biomarker concentrations were compared between the groups with Mann-Whitney test. To compare gender and APOE genotype distributions, Chi-square test was performed. Logistic regression was then used to model the probability of having $\mathrm{AD}$ pathology at

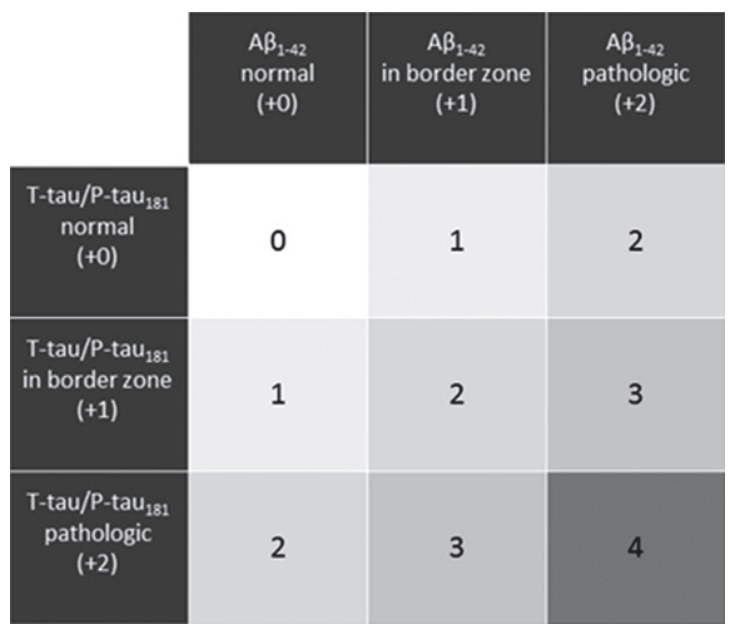

Fig. 1. ES classification pattern based on the CSF biomarker alterations. Points appointed to each biomarker alteration is given between brackets.

the postmortem examination as a function of the ES, whereupon the score was recoded, due to the small number of observations in some categories, into: neurochemically improbable $\mathrm{AD}(\mathrm{ES}=0$ or 1 , the reference category), neurochemically possible $\mathrm{AD}(\mathrm{ER}=2$ or 3$)$, or neurochemically probable $\mathrm{AD}$ $(\mathrm{ES}=4)$, which is in agreement with the wording in the routine laboratory report presented to clinicians. The model was fitted with maximal likelihood, adjusting for gender (with female as the reference category), age, and the time between the LP and death (TLPD). After having the model fitted, marginal probabilities, odds ratios to have AD-pathology on neuropathological examination, and the ROC curve were post-estimated. Statistical modelling was performed with Stata 14.2 (StataCorp, College Station, TX, USA).

\section{RESULTS}

All demographic data and biomarker concentrations are summarized in Table 1. Patient groups differed in age at LP $(p<0.001)$, but not in gender distribution $(p=0.156)$ or TLPD $(p=0.083)$. All biomarkers differed significantly between the groups $(p<0.001)$. Of the 106 definite AD patients, 69 were classified as neurochemically probable $\mathrm{AD}(\mathrm{ES}=4)$, 34 as neurochemically possible $\mathrm{AD}(\mathrm{ES}=2$ or 3$)$, and 3 as neurochemically improbable $\mathrm{AD}(\mathrm{ES}=0$ or 1). On the other hand, 13 of the 57 definite non-AD patients were classified as neurochemically probable 
Table 1

Descriptive table of demographic and biomarker data

\begin{tabular}{|c|c|c|c|}
\hline & $\mathrm{AD}$ & Non-AD & $p$ \\
\hline $\bar{N}$ & 106 & 57 & \\
\hline Gender $(f / m)$ & $47 / 59$ & $18 / 39$ & 0.156 \\
\hline Age at CSF sampling (y) & $77(72-85)^{\mathrm{a}, \mathrm{c}}$ & $70(60-76)^{\mathrm{a}, \mathrm{b}}$ & $<0.001 *$ \\
\hline$T L P D(y)$ & $0.2(0.1-1.5)^{\mathrm{c}}$ & $0.7(0.1-2.1)^{\mathrm{b}}$ & 0.083 \\
\hline AD suggestive IWG-2 algorithm & 84 & 22 & $<0.001 *$ \\
\hline$E S$ & & & $* 0.001 *$ \\
\hline 0 & 2 & 8 & \\
\hline 1 & 1 & 4 & \\
\hline $2-3$ & 34 & 32 & \\
\hline 4 & 69 & 13 & \\
\hline$A \beta_{1-42}(\mathrm{pg} / \mathrm{ml})$ & $389(290-493)^{\mathrm{a}, \mathrm{c}}$ & $585(407-774)^{\mathrm{a}, \mathrm{b}}$ & $<0.001 *$ \\
\hline$T$-tau $(\mathrm{pg} / \mathrm{ml})$ & $570(361-927)^{\mathrm{a}, \mathrm{c}}$ & $336(214-547)^{\mathrm{a}, \mathrm{b}}$ & $<0.001 *$ \\
\hline$P-\operatorname{tau}_{181}(\mathrm{pg} / \mathrm{ml})$ & $65.0(44.6-94.3)^{\mathrm{a}, \mathrm{c}}$ & $39.0(27.2-55.2)^{\mathrm{b}}$ & $<0.001 *$ \\
\hline APOE \&4 (carrier/non-carrier) & $37 / 37$ & $12 / 24$ & $* 0.148 *$ \\
\hline
\end{tabular}

All data are presented as median values and corresponding interquartile ranges between brackets. Significant differences between groups are marked as a significant difference with control group,

${ }^{\mathrm{b}}$ significant difference with AD group, ${ }^{\mathrm{c}}$ significant difference with Non-AD group. The level of significance was set at a $p$-value below $0.05(*)$. Only a fraction (67\%) of cases had APOE genotyping by cause of blood sample availability. $\mathrm{AD}$, Alzheimer's disease; APOE, apolipoprotein E; ES, Erlangen Score; TLPD, time between LP and death.

Table 2

Logistic regression model of the probability to have AD-pathology on the neuropathological examination

\begin{tabular}{lccccc}
\hline Predictors & $\beta$ & Std. Error & $\mathrm{z}$ & $\mathrm{p}$ & $95 \%$ CI \\
\hline ES (ref. 0 or 1) & & & & & \\
$\quad 2$ or 3 & 1.439 & 0.732 & 1.97 & $0.049^{*}$ & 0.004 to 2.873 \\
$\quad 4$ & 2.921 & 0.757 & 3.86 & $<0.001^{*}$ & 1.438 to 4.405 \\
Age $(y)$ & 0.074 & 0.020 & 3.73 & $<0.001^{*}$ & 0.035 to 0.114 \\
Male gender & -0.815 & 0.423 & -1.93 & $0.054^{*}$ & -1.643 to 0.014 \\
TLPD $(y)$ & 0.052 & 0.152 & 0.34 & $0.734^{*}$ & -0.0247 to 0.350 \\
Constant & -6.292 & 1.643 & -3.83 & $<0.001^{*}$ & -9.513 to -3.071 \\
\hline
\end{tabular}

The logistic regression model was performed as a function of the ES, gender, and TLPD. The level of significance was set at a $p$-value below $0.05(*)$. Log likelihood $=-78.72$; Pseudo $\mathrm{R}^{2}=0.2539$; Wald $\chi^{2}(5)=53.57$, $p<0.0001$. AD, Alzheimer's disease; CI, confidence interval; ES, Erlangen Score; TLPD, time between LP and death.

$\mathrm{AD}(\mathrm{ES}=4), 32$ as neurochemically possible $\mathrm{AD}$ ( $\mathrm{ES}=2$ or 3 ), and 12 as neurochemically improbable $\mathrm{AD}(\mathrm{ES}=0$ or 1$)$.

The logistic regression model is presented in Table 2. Compared to the reference category ( $E S=0$ or 1, i.e., neurochemically improbable), both categories, (ES $=2$ or 3, i.e., neurochemically possible) and $\mathrm{ES}=4$ (i.e., neurochemically probable) were significant positive predictors for the probability of having $\mathrm{AD}$ pathology postmortem $(p<0.05$ and $p<0.001$, respectively). Compared to the reference category $(\mathrm{ES}=0$ or 1$)$, the group classified as neurochemically possible $\mathrm{AD}$ ( $\mathrm{ES}=2$ or 3 ) had odds 4.22 times greater to have AD pathology on the postmortem examination, and the group classified as neurochemically probable $\mathrm{AD}(\mathrm{ES}=4)$ had odds 18.6 times greater. Compared to the neurochemically possible group, the odds of the neurochemically probable group were 4.4 times greater (Fig. 2). Of the explanatory variables, only age showed significant positive effect $(p<0.001)$, with every year of age increasing the odds by $8 \%$, while the effect of gender was borderline insignificant $(p=0.054)$, and the effect of TLPD was insignificant.

The ROC curve comparing the two groups, postestimated from the above logistic model, resulted in an area under the curve (AUC) of 0.821 [95\%CI: 0.750 to 0.893 ], which was significantly larger $(p<0.05)$ compared to the AUC $(0.737$ [95\%CI: 0.656 to 0.819$]$ ) of the ROC curve, resulting from the model with ES as the sole explanatory variable. 


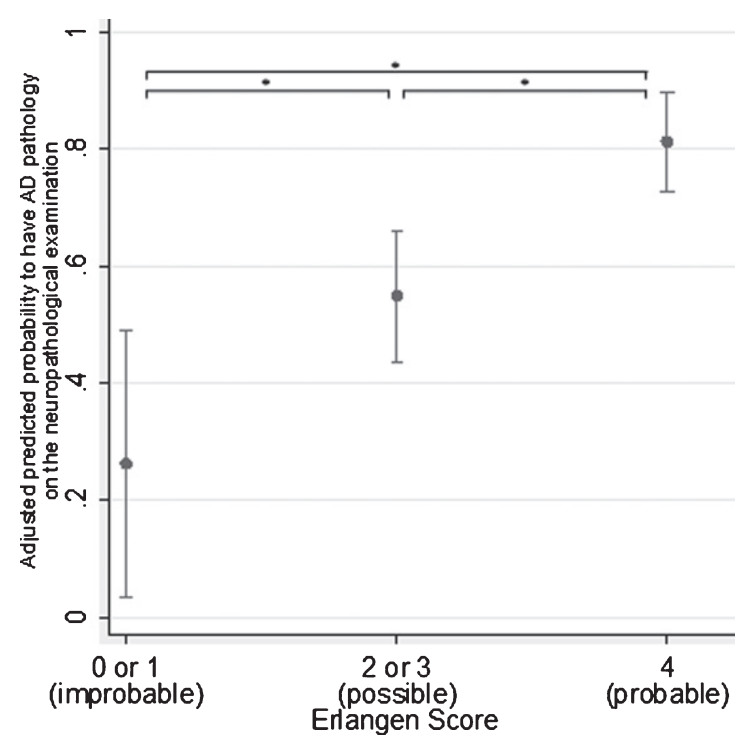

Fig. 2. Marginal predictions of the probability to have AD pathology at the postmortem examination. Predications were made at the fixed values of the overall average of age and TLPD and the overall proportion of females across the groups. The level of significance was set at a $p$-value below $0.05(*)$.

\section{DISCUSSION}

In order to enable comparison of interpretations of $\mathrm{AD}$ biomarkers measurements across laboratories applying different preanalytical handling procedures, analytical methods, cut-offs or even different sets of the biomarkers, the ES interpretation algorithm was proposed in a previous study [16] and validated on two other large-scale multicenter cohorts [17]. In the current study, the ES algorithm enabled a correct prediction of the postmortem neuropathological outcome on the ground of the intra vitam CSF results of three core AD biomarkers. The probabilities to have $\mathrm{AD}$ pathology postmortem in contrast to nonAD pathologies including mainly FTLD, vascular dementia, and LBD increased almost linearly with increasing ES ordered categories. To this end, the results presented here are entirely in line with the previously published report showing prediction of the disease progression based on the ES outcome [17].

Less than $3 \%$ of the neuropathologically definite $\mathrm{AD}$ patients (3 out of 106) were categorized as neurochemically improbable $\mathrm{AD}(\mathrm{ES}=0$ or 1$)$. Foremost, these patients were in the earlier stages of AD pathology based on the Montine criteria (Supplementary Table 1). According to the amyloid cascade hypothesis, the prevailing theory of AD etiology, $A \beta_{1-42}$ is attributed a central role as an initiator of
AD pathology. This implies that $A \beta_{1-42}$ is the first biomarker to change in the CSF, before changes reflecting neurofibrillary tangles and neurodegeneration (CSF P-tau 181 and T-tau) can be detected [26]. Also, borderline values in the "normal" range and relative longer TLPD may have contributed to lower ES than expected. Further, it should be taken into consideration that neuropathological alterations in different areas of the brain may be reflected in the CSF to different extents, depending on their distance to the CSF space and the dynamic pathway the molecules need to diffuse to reach the CSF. Yet another potential explanation is that only $A \beta_{1-42}$ was included in this study as a biomarker of amyloidosis, without considering $A \beta_{1-42} / A \beta_{1-40}$, which was unavailable. Therefore, it is plausible to speculate that some cases without alterations in $A \beta_{1-42}$, and hence interpreted as not having amyloid-related alterations, may have turned into amyloid-positive if $A \beta_{1-42} / A \beta_{1-40}$ had been measured [27].

On the other hand, we observed that $23 \%$ (13 out of $57)$ of the definite non-AD patients, which were categorized as neurochemically probable $\mathrm{AD}(\mathrm{ES}=4)$. This, in turn, is in line with the presence of concomitant $\mathrm{AD}$ pathology in non-AD dementia patients, as reported previously [28-30]. Indeed, many of the non-AD cases in this study that had an ES suggestive for $\mathrm{AD}$ pathological findings $(n=7)$, presented with AD-related neuropathological changes that may have had a higher impact than expected. Although these cases seemingly decrease diagnostic accuracy of the CSF biomarkers, and in consequence the ES, their inclusion is most representable for the general population. P-tau 181 has previously demonstrated to be the most specific marker for $\mathrm{AD}$, in contrast to $\mathrm{T}$ tau $[4,5,31]$, and hence it must be stressed that the current version of the ES, treating all three (or four) CSF biomarkers equally weighted, shows a considerable limitation from the point of view of specificity, favoring diagnostic sensitivity. Lack of studies on the harmonization of CSF biomarker interpretation in light of the differentiation of $\mathrm{AD}$ against non-AD dementias makes this study potentially interesting particularly in the scenarios where biomarker results must be compared across centers, the more so as a large cohort of neuropathologically confirmed AD and non-AD cases was included.

Despite lack of $A \beta_{1-40}$ results in this cohort, which is probably the strongest limitation of the study, the ES proved to correctly categorize the vast majority of the patients, reconfirming its utility as an interpretation algorithm. As $A \beta_{1-40}$ is the most abundant 
and stable isoform, its addition obviously further increases the diagnostic performance by eliminating the inter-individual variability of high or low content of total $A \beta$ peptides [27, 32-38] and correcting for other non-AD-specific subcortical changes that may alter the overall $A \beta$ levels in the brain [39].

Other biomarker combinations have also been shown to have an accurate differential diagnostic performance for the discrimination of $\mathrm{AD}$ from non-AD dementia with high AUC values. Our previous study showed that the diagnostic accuracy for the differentiation of autopsy-confirmed $\mathrm{AD}$ from autopsy-confirmed non-AD, achieved AUC values of 0.647 for $A \beta_{1-42}$ alone, 0.670 for $\mathrm{T}$-tau alone, and 0.676 for $\mathrm{P}-\operatorname{tau}_{181}$ alone, while for their ratios AUC values of 0.635 for the $A \beta_{1-42} / \mathrm{T}$-tau ratio and 0.734 for the $A \beta_{1-42} / \mathrm{P}-\operatorname{tau}_{181}$ ratio were obtained [4]. However, these ratios may not overcome biomarker variability as (pre-) analytical effects on both biomarkers included in such ratios may still differ [40], even when analyses are performed by automated methods that increase standardization and precision of CSF biomarker measurements [41]. The introduction of certified reference material calibrated ELISA kits may therefore provide further improvement for standardization of CSF biomarker measurements and may eventually enable the introduction of worldwide, biomarker-specific instead of center-specific cutoffs [42-44].

\section{Conclusion}

In light of improving the differential diagnosis of $\mathrm{AD}$, this validation of the ES demonstrated the categorization of $\mathrm{AD}$ and non-AD subjects with reasonable diagnostic accuracy. The ability of the ES to overcome the high variability of raw CSF biomarker data may provide a useful diagnostic tool for comparing neurochemical diagnosis between different labs or methods used, independently of their specific cutoffs.

\section{ACKNOWLEDGMENTS}

This research was funded in part by the University of Antwerp Research Fund; unrestrictive research grants from Janssen Pharmaceutica NV and ADx Neurosciences; the Institute Born-Bunge; the Flanders Impulse Program on Networks for Dementia Research (VIND); the agency of Flanders Innovation \& Intrepreneurship (VLAIO, http://www.vlaio.be).
The research leading to these results has also received support from the Innovative Medicines Initiative Joint Undertaking under EMIF grant agreement $\mathrm{n}^{\circ} 115372$, resources of which are composed of financial contribution from the European Union's Seventh Framework Programme (FP7/2007-2013) and EFPIA companies' in kind contribution. Uitgegeven met steun van de Universitaire Stichting van België.

Authors' disclosures available online (https:// www.j-alz.com/manuscript-disclosures/18-0563r1).

\section{SUPPLEMENTARY MATERIAL}

The supplementary material is available in the electronic version of this article: http://dx.doi.org/ 10.3233/JAD-180563.

\section{REFERENCES}

[1] Engelborghs S, De Vreese K, Van de Casteele T, Vanderstichele H, Van Everbroeck B, Cras P, Martin J-J, Vanmechelen E, De Deyn PP (2008) Diagnostic performance of a CSF-biomarker panel in autopsy-confirmed dementia. Neurobiol Aging 29, 1143-1159.

[2] Lewczuk P, Riederer P, O'Bryant SE, Verbeek MM, Dubois B, Visser PJ, Jellinger KA, Engelborghs S, Ramirez A, Parnetti L, Jack CR, Teunissen CE, Hampel H, Lleó A, Jessen F, Glodzik L, de Leon MJ, Fagan AM, Molinuevo JL, Jansen WJ, Winblad B, Shaw LM, Andreasson U, Otto M, Mollenhauer B, Wiltfang J, Turner MR, Zerr I, Handels R, Thompson AG, Johansson G, Ermann N, Trojanowski JQ, Karaca I, Wagner H, Oeckl P, van Waalwijk van Doorn L, Bjerke M, Kapogiannis D, Kuiperij HB, Farotti L, Li Y, Gordon BA, Epelbaum S, Vos SJB, Klijn CJM, Van Nostrand WE, Minguillon C, Schmitz M, Gallo C, Lopez Mato A, Thibaut F, Lista S, Alcolea D, Zetterberg H, Blennow K, Kornhuber J, Members of the WFSBP Task Force Working on this Topic: Peter Riederer, Carla Gallo, Dimitrios Kapogiannis, Andrea Lopez Mato FT (2018) Cerebrospinal fluid and blood biomarkers for neurodegenerative dementias: An update of the Consensus of the Task Force on Biological Markers in Psychiatry of the World Federation of Societies of Biological Psychiatry. World J Biol Psychiatry 19, 244-328.

[3] Dubois B, Feldman HH, Jacova C, Hampel H, Molinuevo JL, Blennow K, DeKosky ST, Gauthier S, Selkoe D, Bateman R, Cappa S, Crutch S, Engelborghs S, Frisoni GB, Fox NC, Galasko D, Habert M-O, Jicha GA, Nordberg A, Pasquier F, Rabinovici G, Robert P, Rowe C, Salloway S, Sarazin M, Epelbaum S, de Souza LC, Vellas B, Visser PJ, Schneider L, Stern Y, Scheltens P, Cummings JL (2014) Advancing research diagnostic criteria for Alzheimer's disease: The IWG-2 criteria. Lancet Neurol 13, 614-629.

[4] Somers C, Struyfs H, Goossens J, Niemantsverdriet E, Luyckx J, De Roeck N, De Roeck E, De Vil B, Cras P, Martin 
J-J, De Deyn P-P, Bjerke M, Engelborghs S (2016) A decade of cerebrospinal fluid biomarkers for Alzheimer's disease in Belgium. J Alzheimers Dis 54, 383-395.

[5] Struyfs H, Niemantsverdriet E, Goossens J, Fransen E, Martin J-J, De Deyn PP, Engelborghs S (2015) Cerebrospinal fluid P-Tau181P: Biomarker for improved differential dementia diagnosis. Front Neurol 6, 138.

[6] Vos SJB, Visser PJ, Verhey F, Aalten P, Knol D, Ramakers I, Scheltens P, Rikkert MGMO, Verbeek MM, Teunissen CE (2014) Variability of CSF Alzheimer's disease biomarkers: Implications for clinical practice. PLoS One $\mathbf{9}$, e100784.

[7] Bjerke M, Portelius E, Minthon L, Wallin A, Anckarsäter H, Anckarsäter R, Andreasen N, Zetterberg H, Andreasson U, Blennow K (2010) Confounding factors influencing amyloid Beta concentration in cerebrospinal fluid. Int $J$ Alzheimers Dis 2010, 1-11.

[8] Mattsson N, Andreasson U, Persson S, Arai H, Batish SD, Bernardini S, Bocchio-Chiavetto L, Blankenstein MA, Carrillo MC, Chalbot S, Coart E, Chiasserini D, Cutler N, Dahlfors G, Duller S, Fagan AM, Forlenza O, Frisoni GB, Galasko D, Galimberti D, Hampel H, Handberg A, Heneka MT, Herskovits AZ, Herukka S-K, Holtzman DM, Humpel C, Hyman BT, Iqbal K, Jucker M, Kaeser SA, Kaiser E, Kapaki E, Kidd D, Klivenyi P, Knudsen CS, Kummer MP, Lui J, Lladó A, Lewczuk P, Li Q-X, Martins R, Masters C, McAuliffe J, Mercken M, Moghekar A, Molinuevo JL, Montine TJ, Nowatzke W, O'Brien R, Otto M, Paraskevas GP, Parnetti L, Petersen RC, Prvulovic D, de Reus HPM, Rissman RA, Scarpini E, Stefani A, Soininen H, Schröder J, Shaw LM, Skinningsrud A, Skrogstad B, Spreer A, Talib L, Teunissen C, Trojanowski JQ, Tumani H, Umek RM, Van Broeck B, Vanderstichele H, Vecsei L, Verbeek MM, Windisch M, Zhang J, Zetterberg H, Blennow K (2011) The Alzheimer's Association external quality control program for cerebrospinal fluid biomarkers. Alzheimers Dement 7 , 386-395.e6.

[9] Fourier A, Portelius E, Zetterberg H, Blennow K, Quadrio I, Perret-Liaudet A (2015) Pre-analytical and analytical factors influencing Alzheimer's disease cerebrospinal fluid biomarker variability. Clin Chim Acta 449, 9-15.

[10] Le Bastard N, De Deyn PP, Engelborghs S (2015) Importance and impact of preanalytical variables on Alzheimer disease biomarker concentrations in cerebrospinal fluid. Clin Chem 61, 734-743.

[11] Leitão MJ, Baldeiras I, Herukka S-K, Pikkarainen M, Leinonen V, Simonsen AH, Perret-Liaudet A, Fourier A, Quadrio I, Veiga PM, de Oliveira CR (2015) Chasing the effects of pre-analytical confounders - a multicenter study on CSF-AD biomarkers. Front Neurol 6, 153.

[12] Engelborghs S, Niemantsverdriet E, Struyfs H, Blennow K, Brouns R, Comabella M, Dujmovic I, van der Flier W, Frölich L, Galimberti D, Gnanapavan S, Hemmer B, Hoff E, Hort J, Iacobaeus E, Ingelsson M, Jan de Jong F, Jonsson M, Khalil M, Kuhle J, Lleó A, de Mendonça A, Molinuevo JL, Nagels G, Paquet C, Parnetti L, Roks G, Rosa-Neto P, Scheltens P, Skårsgard C, Stomrud E, Tumani H, Visser PJ, Wallin A, Winblad B, Zetterberg H, Duits F, Teunissen CE (2017) Consensus guidelines for lumbar puncture in patients with neurological diseases. Alzheimers Dement (Amst) 8, 111-126.

[13] del Campo M, Mollenhauer B, Bertolotto A, Engelborghs S, Hampel H, Simonsen AH, Kapaki E, Kruse N, Le Bastard N, Lehmann S, Molinuevo JL, Parnetti L, Perret-Liaudet A, Sáez-Valero J, Saka E, Urbani A, Vanmechelen E, Verbeek
M, Visser PJ, Teunissen C (2012) Recommendations to standardize preanalytical confounding factors in Alzheimer's and Parkinson's disease cerebrospinal fluid biomarkers: An update. Biomark Med 6, 419-430.

[14] Vanderstichele H, Bibl M, Engelborghs S, Le Bastard N, Lewczuk P, Molinuevo JL, Parnetti L, Perret-Liaudet A, Shaw LM, Teunissen C, Wouters D, Blennow K (2012) Standardization of preanalytical aspects of cerebrospinal fluid biomarker testing for Alzheimer's disease diagnosis: A consensus paper from the Alzheimer's Biomarkers Standardization Initiative. Alzheimers Dement 8, 65-73.

[15] Vanderstichele H, Demeyer L, Janelidze S, Coart E, Stoops E, Mauroo K, Herbst V, François C, Hansson O (2017) Recommendations for cerebrospinal fluid collection for the analysis by ELISA of neurogranin trunc P75, $\alpha$-synuclein, and total tau in combination with $A \beta(1-42) / A \beta(1-40)$. Alzheimers Res Ther $\mathbf{9}, 40$.

[16] Lewczuk P, Zimmermann R, Wiltfang J, Kornhuber J (2009) Neurochemical dementia diagnostics: A simple algorithm for interpretation of the CSF biomarkers. J Neural Transm 116, 1163-1167.

[17] Lewczuk P, Kornhuber J, Toledo JB, Trojanowski JQ, Knapik-Czajka M, Peters O, Wiltfang J, Shaw LM (2015) Validation of the Erlangen score algorithm for the prediction of the development of dementia due to Alzheimer's disease in pre-dementia subjects. J Alzheimers Dis 48, 433-441.

[18] Montine TJ, Phelps CH, Beach TG, Bigio EH, Cairns NJ, Dickson DW, Duyckaerts C, Frosch MP, Masliah E, Mirra SS, Nelson PT, Schneider JA, Thal DR, Trojanowski JQ, Vinters HV, Hyman BT (2012) National Institute on Aging-Alzheimer's Association guidelines for the neuropathologic assessment of Alzheimer's disease: A practical approach. Acta Neuropathol 123, 1-11.

[19] McKeith IG, Boeve BF, Dickson DW, Halliday G, Taylor J-P, Weintraub D, Aarsland D, Galvin J, Attems J, Ballard CG, Bayston A, Beach TG, Blanc F, Bohnen N, Bonanni L, Bras J, Brundin P, Burn D, Chen-Plotkin A, Duda JE, ElAgnaf O, Feldman H, Ferman TJ, Ffytche D, Fujishiro H, Galasko D, Goldman JG, Gomperts SN, Graff-Radford NR, Honig LS, Iranzo A, Kantarci K, Kaufer D, Kukull W, Lee VMY, Leverenz JB, Lewis S, Lippa C, Lunde A, Masellis M, Masliah E, McLean P, Mollenhauer B, Montine TJ, Moreno E, Mori E, Murray M, O'Brien JT, Orimo S, Postuma RB, Ramaswamy S, Ross OA, Salmon DP, Singleton A, Taylor A, Thomas A, Tiraboschi P, Toledo JB, Trojanowski JQ, Tsuang D, Walker Z, Yamada M, Kosaka K (2017) Diagnosis and management of dementia with Lewy bodies: Fourth consensus report of the DLB Consortium. Neurology 89, 88-100.

[20] Deramecourt V, Slade JY, Oakley AE, Perry RH, Ince PG, Maurage C-A, Kalaria RN (2012) Staging and natural history of cerebrovascular pathology in dementia. Neurology 78, 1043-1050.

[21] Cairns NJ, Bigio EH, Mackenzie IR, Neumann M, Lee VM-Y, Hatanpaa KJ, White CL, Schneider JA, Grinberg LT, Halliday G, Duyckaerts C, Lowe JS, Holm IE, Tolnay M, Okamoto K, Yokoo H, Murayama S, Woulfe J, Munoz DG, Dickson DW, Ince PG, Trojanowski JQ, Mann DMA (2007) Neuropathologic diagnostic and nosologic criteria for frontotemporal lobar degeneration: Consensus of the Consortium for Frontotemporal Lobar Degeneration. Acta Neuropathol 114, 5-22.

[22] Mackenzie IRA, Neumann M, Baborie A, Sampathu DM, Du Plessis D, Jaros E, Perry RH, Trojanowski JQ, Mann 
DMA, Lee VMY (2011) A harmonized classification system for FTLD-TDP pathology. Acta Neuropathol 122, 111-113.

[23] Mackenzie IRA, Neumann M, Bigio EH, Cairns NJ, Alafuzoff I, Kril J, Kovacs GG, Ghetti B, Halliday G, Holm IE, Ince PG, Kamphorst W, Revesz T, Rozemuller AJM, Kumar-Singh S, Akiyama H, Baborie A, Spina S, Dickson DW, Trojanowski JQ, Mann DMA (2010) Nomenclature and nosology for neuropathologic subtypes of frontotemporal lobar degeneration: An update. Acta Neuropathol 119, $1-4$.

[24] Dickson DW, Bergeron C, Chin SS, Duyckaerts C, Horoupian D, Ikeda K, Jellinger K, Lantos PL, Lippa CF, Mirra SS, Tabaton M, Vonsattel JP, Wakabayashi K, Litvan I (2002) Office of Rare Diseases neuropathologic criteria for corticobasal degeneration. J Neuropathol Exp Neurol 61, 935-946.

[25] Van der Mussele S, Fransen E, Struyfs H, Luyckx J, Mariën P, Saerens J, Somers N, Goeman J, De Deyn PP, Engelborghs S (2014) Depression in mild cognitive impairment is associated with progression to Alzheimer's disease: A longitudinal study. J Alzheimers Dis 42, 1239-1250.

[26] Buchhave P, Minthon L, Zetterberg H, Wallin AK, Blennow K, Hansson O (2012) Cerebrospinal fluid levels of $\beta$ amyloid $1-42$, but not of tau, are fully changed already 5 to 10 years before the onset of Alzheimer dementia. Arch Gen Psychiatry 69, 98-106.

[27] Niemantsverdriet E, Ottoy J, Somers C, De Roeck E, Struyfs H, Soetewey F, Verhaeghe J, Van den Bossche T, Van Mossevelde S, Goeman J, De Deyn PP, Mariën P, Versijpt J, Sleegers K, Van Broeckhoven C, Wyffels L, Albert A, Ceyssens S, Stroobants S, Staelens S, Bjerke M, Engelborghs $S$ (2017) The cerebrospinal fluid $A \beta 1-42 / A \beta 1-40$ ratio improves concordance with amyloid-PET for diagnosing Alzheimer's disease in a clinical setting. J Alzheimers Dis 60, 561-576.

[28] Rosso SM, Kamphorst W, Ravid R, van Swieten JC (2000) Coexistent tau and amyloid pathology in hereditary frontotemporal dementia with tau mutations. Ann N Y Acad Sci 920, 115-9.

[29] Ghoshal N, Cali I, Perrin RJ, Josephson SA, Sun N, Gambetti P, Morris JC (2009) Codistribution of amyloid $\beta$ plaques and spongiform degeneration in familial Creutzfeldt-Jakob disease with the E200K-129M haplotype. Arch Neurol 66, 71-80.

[30] Slaets S, Le Bastard N, Theuns J, Sleegers K, Verstraeten A, De Leenheir E, Luyckx J, Martin J-J, Van Broeckhoven C, Engelborghs S (2013) Amyloid pathology influences aß142 cerebrospinal fluid levels in dementia with Lewy bodies. J Alzheimers Dis 35, 137-146.

[31] Koopman K, Le Bastard N, Martin J-J, Nagels G, De Deyn PP, Engelborghs S (2009) Improved discrimination of autopsy-confirmed Alzheimer's disease (AD) from nonAD dementias using CSF P-tau181P. Neurochem Int 55, 214-218.

[32] Wiltfang J, Esselmann H, Bibl M, Hüll M, Hampel H, Kessler H, Frölich L, Schröder J, Peters O, Jessen F, Luckhaus C, Perneczky R, Jahn H, Fiszer M, Maler JM, Zimmermann R, Bruckmoser R, Kornhuber J, Lewczuk P (2007) Amyloid $\beta$ peptide ratio $42 / 40$ but not $A \beta 42$ correlates with phospho-Tau in patients with low- and high-CSF Aß40 load. J Neurochem 101, 1053-1059.

[33] Lewczuk P, Lelental N, Spitzer P, Maler JM, Kornhuber J (2014) Amyloid- $\beta$ 42/40 cerebrospinal fluid concentration ratio in the diagnostics of Alzheimer's disease: Validation of two novel assays. J Alzheimers Dis 43, 183-191.
[34] Dorey A, Perret-Liaudet A, Tholance Y, Fourier A, Quadrio I (2015) Cerebrospinal fluid $A \beta 40$ improves the interpretation of $\mathrm{A} \beta 42$ concentration for diagnosing Alzheimer's disease. Front Neurol 6, 247.

[35] Janelidze S, Zetterberg H, Mattsson N, Palmqvist S, Vanderstichele H, Lindberg O, van Westen D, Stomrud E, Minthon L, Blennow K, Swedish BioFINDER study group, Hansson $O$ (2016) CSF $A \beta 42 / A \beta 40$ and $A \beta 42 / A \beta 38$ ratios: Better diagnostic markers of Alzheimer disease. Ann Clin Transl Neurol 3, 154-165.

[36] Somers C, Goossens J, Engelborghs S, Bjerke M (2017) Selecting $A \beta$ isoforms for an Alzheimer's disease cerebrospinal fluid biomarker panel. Biomark Med 11, 169-178.

[37] Struyfs H, Van Broeck B, Timmers M, Fransen E, Sleegers K, Van Broeckhoven C, De Deyn PP, Streffer JR, Mercken M, Engelborghs S (2015) Diagnostic accuracy of cerebrospinal fluid amyloid- $\beta$ isoforms for early and differential dementia diagnosis. J Alzheimers Dis $\mathbf{4 5}$, 813-822.

[38] Lewczuk P, Matzen A, Blennow K, Parnetti L, Molinuevo JL, Eusebi P, Kornhuber J, Morris JC, Fagan AM (2017) Cerebrospinal fluid $A \beta 42 / 40$ corresponds better than $A \beta 42$ to amyloid PET in Alzheimer's disease. J Alzheimers Dis 55, 813-822.

[39] Selnes P, Blennow K, Zetterberg H, Grambaite R, Rosengren L, Johnsen L, Stenset V, Fladby T (2010) Effects of cerebrovascular disease on amyloid precursor protein metabolites in cerebrospinal fluid. Cerebrospinal Fluid Res 7, 10 .

[40] Dumurgier J, Vercruysse O, Paquet C, Bombois S, Chaulet C, Laplanche J-L, Peoc'h K, Schraen S, Pasquier F, Touchon J, Hugon J, Lehmann S, Gabelle A (2013) Intersite variability of CSF Alzheimer's disease biomarkers in clinical setting. Alzheimers Dement 9, 406-413.

[41] Bittner T, Zetterberg H, Teunissen CE, Ostlund RE, Militello M, Andreasson U, Hubeek I, Gibson D, Chu DC, Eichenlaub U, Heiss P, Kobold U, Leinenbach A, Madin K, Manuilova E, Rabe C, Blennow K (2016) Technical performance of a novel, fully automated electrochemiluminescence immunoassay for the quantitation of $\beta$-amyloid (1-42) in human cerebrospinal fluid. Alzheimers Dement 12, 517-526.

[42] Bjerke M, Andreasson U, Kuhlmann J, Portelius E, Pannee J, Lewczuk P, Umek RM, Vanmechelen E, Vanderstichele H, Stoops E, Lewis J, Vandijck M, Kostanjevecki V, Jeromin A, Salamone SJ, Schmidt O, Matzen A, Madin K, Eichenlaub U, Bittner T, Shaw LM, Zegers I, Zetterberg H, Blennow K (2016) Assessing the commutability of reference material formats for the harmonization of amyloid- $\beta$ measurements. Clin Chem Lab Med 54, 1177-1191.

[43] Kuhlmann J, Andreasson U, Pannee J, Bjerke M, Portelius E, Leinenbach A, Bittner T, Korecka M, Jenkins RG, Vanderstichele H, Stoops E, Lewczuk P, Shaw LM, Zegers I, Schimmel H, Zetterberg H, Blennow K, IFCC Working Group on Standardization of CSF proteins (WGCSF) (2017) CSF A 1-42 - an excellent but complicated Alzheimer's biomarker - a route to standardisation. Clin Chim Acta 467, 27-33.

[44] Andreasson U, Kuhlmann J, Pannee J, Umek RM, Stoops E, Vanderstichele H, Matzen A, Vandijck M, Dauwe M, Leinenbach A, Rutz S, Portelius E, Zegers I, Zetterberg H, Blennow K (2018) Commutability of the certified reference materials for the standardization of $\beta$-amyloid 1-42 assay in human cerebrospinal fluid: Lessons for tau and 
$\beta$-amyloid 1-40 measurements. Clin Chem Lab Med 56, 2058-2066

[45] Thal DR, Rüb U, Orantes M, Braak H (2002) Phases of A beta-deposition in the human brain and its relevance for the development of AD. Neurology 58, 1791-1800.

[46] Braak H, Braak E (1991) Neuropathological stageing of Alzheimer-related changes. Acta Neuropathol 82, 239-259.
[47] Braak H, Alafuzoff I, Arzberger T, Kretzschmar H, Tredici K (2006) Staging of Alzheimer disease-associated neurofibrillary pathology using paraffin sections and immunocytochemistry. Acta Neuropathol 112, 389-404. 